\title{
EFFECTS OF OXALATE INTAKE ON CALCIUM AND PHOSPHORUS BALANCE IN BULLS FED NAPIER SILAGE (Pennisetum purpureum)
}

\author{
N. G. Das ${ }^{1}$, K. S. Huque ${ }^{1}$, M. R. Alam ${ }^{2}$, N. Sultana ${ }^{1}$ and S. M. Amanullah ${ }^{1}$
}

\begin{abstract}
An experiment was conducted to examine the effects of oxalate intake on calcium and phosphorus balance in bulls fed Napier silage. Eighteen growing bulls having average live weight of $249 \pm 8.38 \mathrm{Kg}$ and aged about 40 months were divided into three groups of six animals in each group. They were assigned to dietary treatments $\mathrm{T}_{0}$ (considered as control), $T_{1}$ and $T_{2}$ consisting of rice straw, rice straw and Napier silage (1:1, DM basis) and Napier silage ad libitum, respectively for a period of 21 days. A concentrate mixture composed of $940 \mathrm{~g}$ wheat bran, 60g dicalcium phosphate (DCP) and 50g common salt was fed to each bull at the rate of $1.05 \mathrm{Kg} / \mathrm{d}$. With the increase of Napier silage intake there was a significant $(\mathrm{P}<0.01)$ increase of oxalate intake $(17.91,24.65$ and $30.97 \mathrm{~g} / \mathrm{d}$, with $\mathrm{T}_{0}, \mathrm{~T}_{1}$ and $\mathrm{T}_{2}$ diets, respectively) with the subsequent increase of $(\mathrm{P}<0.01)$ their excretion through feces $(3.02,8.66$ and $11.02 \mathrm{~g} / \mathrm{d}$, respectively). The fecal and urinary excretion of calcium (11.41, 18.25 and $25.28 \mathrm{~g} / \mathrm{d}$, respectively) and phosphorus (13.37, 16.85 and 20.09 g/d, respectively) of the animals fed different diets were significantly $(\mathrm{P}<0.05)$ high when the straw diet was replaced with 50 and $100 \%$ Napier silage, respectively and there were calcium and phosphorus deficiencies in bulls fed Napier silage. Thus, Napier silage diets brought about a significant $(\mathrm{P}<0.05)$ reduction in calcium (12.19, 6.87 and $1.36 \mathrm{~g} / \mathrm{d}$, respectively) and phosphorus (7.17, 6.40 and $5.39 \mathrm{~g} / \mathrm{d}$, respectively) balances though the intake of these two minerals were adequate showing linear reverse relationship with the increase of oxalate intake from Napier silage.
\end{abstract}

Key words: Napier silage, Oxalate, Calcium, Phosphorus, Bull

\section{Introduction}

Scarcity of feed is one of the important problems in Bangladesh for rearing livestock. To mitigate this problem, Bangladesh Livestock Research Institute (BLRI) introduced Napier grass (Pennisetum purpureum) during 1988 to 2005 in Pabna and Sirajgonj districts, known as potential milk production areas of the country with the help of Milk Vita. Farmers frequently harvest lush pasture of Napier grass grown on very fertile soil and feed as sole roughage. Despite increased daily milk production farmers experienced that feeding fresh Napier grass resulted in soft dung, weakness and poor body condition (Huque et al., 2006).

\footnotetext{
${ }^{1}$ Bangladesh Livestock Research Institute, Savar, Dhaka-1341, Bangladesh

${ }^{2}$ Department of Animal Science, Bangladesh Agricultural University, Mymensingh-2202, Bangladesh
}

(Received: April 21, 2010) 
Bang. J. Anim. Sci. 2010, 39(1\&2)

This might be due to the presence of oxalate in the grass and feeding Napier to cows might lead to ingestion of oxalate above their dietary tolerance level which might have an effect on mineral metabolism of these animals. Rahman et al. (2006) found that oxalate content of Napier was as high as $3.77 \%$ of dry matter in early summer season. So, there is a need to determine how the oxalate content of Napier grass affects calcium and phosphorus metabolism in animal body and to develop techniques for overcoming oxalate problem in ruminants thriving on Napier grass. The present work was undertaken to determine the effect of feeding Napier silage on calcium and phosphorus balance in bull.

\section{Materials and Methods}

\section{Site of the experiment}

The study was carried out at the Animal Research Station, Bangladesh Livestock Research Institute (BLRI), Savar, Dhaka for a period of 21 days. The chemical analyses of feed, refusals, feces and urine were done in the Animal Nutrition Laboratory of BLRI. Eighteen bulls with an average live weight of $249 \pm 8.38 \mathrm{Kg}$ and approximately 40 months of age were selected for the experiment. The animals were dewormed with Andex (Novartis), ear tagged, and then allowed for 14 days to adjust with experimental diets and management prior to commencement of the study. The animals were then divided into three groups of six bulls in each group. The animals were housed individually in a well-ventilated face-out concrete digestion crates during the entire trial period.

\section{Dietary treatments}

The experiment was conducted in a Completely Randomized Design (CRD). The length of the trial was 21 days having 14 days of adjustment and 7 days of experimental period. During the whole trial period bulls belonged to treatment group $\mathrm{T}_{0}$ (considered as control), $\mathrm{T}_{1}$ and $\mathrm{T}_{2}$ were offered rice straw ad libitum, 1:1 ratio of rice straw and Napier silage (DM basis) and Napier silage ad libitum, respectively. To avoid selection rice straw was chopped into $2 \mathrm{~cm}$ length and was mixed thoroughly with Napier silage. The DM of the feed and refusals of each of the animal were collected and weighted daily to calculate daily dry matter intake. Fresh and clean drinking water was available to all the animals. Silage was used for the experiment to prevent variation in oxalate intake with the advancement of maturity of grass during the study period. In addition, dicalcium phosphate (DCP) as a sole supplementary source of calcium and phosphorus was used in this experiment. To keep the number of sources of calcium and phosphorus minimum only 60g DCP, 940g wheat bran and $50 \mathrm{~g}$ common salt were weighed, mixed and supplied at 8:00 AM in separate bowls to each animal regularly during the whole experimental period. No refusals of concentrate mixture were found in any case.

\section{Sample collection and analysis}

The quantity of feed, refusal and feces were weighed daily and representative samples were kept for analysis. A part of each sample was kept in a deep freeze at $-20^{\circ} \mathrm{C}$, and later they 
were mixed well and representative samples were used for determination of calcium and phosphorus contents. Urine was collected in buckets, containing $250 \mathrm{ml}$ of $40 \%$ sulfuric acid kept under the outlets of digestion crates. The actual volume of urine was calculated by subtracting $250 \mathrm{ml}$ from the total volume and clean water was added to make a constant volume of 15 liters. Samples of urine were filtered and collected in $100 \mathrm{ml}$ plastic bottles and stored in a deep freeze at $-20^{\circ} \mathrm{C}$ until analysis. The oxalate contents of all samples were analyzed by titration method according to Abaza et al., 1968. Calcium and phosphorus contents were determined by Atomic Absorption Spectrometry method (Varma, 1985; Atomic Absorption Spectrophotometer, MODEL 210 VGP, Buck scientific) and Colorimetric method (Fiske and Subbarow, 1925; T60 spectrophotometer, THURAMED. Louisville, KY. USA), respectively. Proximate analysis of feed and refusals were analyzed in duplicate following the method of AOAC (1990).

\section{Statistical analysis}

The data were evaluated statistically using SPSS 11.5 software using analysis of variance (ANOVA) in a Completely Randomized Design (CRD) to determine significance and least significant difference (LSD) was used to determine significant differences among the treatment means following the method described by Steel and Torrie (1980).

\section{Results and Discussion}

\section{Chemical composition of feedstuffs}

The chemical composition of feeds used in this experiment is given in Table 1. From the chemical composition of roughage and concentrate mixture it is seen that the calcium, phosphorus and oxalate contents of rice straw $(0.23,0.16$ and $0.52 \%$, respectively) were lower than that of Napier silage $(0.31,0.28$ and $0.86 \%$, respectively) but that of mixture of rice straw and Napier silage (1:1, DM basis) were intermediate $(0.27,0.22$ and $0.69 \%$, respectively). The highest calcium and phosphorus content in concentrate mixture (1.62 \% for each) was due to the use of DCP in diet. The source of very low level of oxalate content of concentrate mixture was wheat bran.

Table 1. Chemical composition of feedstuffs

\begin{tabular}{|l|c|c|c|c|c|c|}
\hline \multicolumn{1}{|c|}{ Feed items } & \% fresh & \multicolumn{7}{c|}{ \% DM } \\
\cline { 2 - 7 } & DM & OM & Ash & Ca & P & Oxalate \\
\hline Rice straw & 90.29 & 87.71 & 12.29 & 0.23 & 0.16 & 0.52 \\
Rice straw + Napier silage (1:1) & 54.11 & 86.55 & 13.45 & 0.27 & 0.22 & 0.69 \\
Napier silage & 17.93 & 85.40 & 14.60 & 0.31 & 0.28 & 0.86 \\
Concentrate mixture & 91.43 & 88.84 & 11.16 & 1.62 & 1.62 & 0.01 \\
\hline
\end{tabular}


Bang. J. Anim. Sci. 2010, 39(1\&2)

\section{Intake of feed nutrients}

Data on intake of feeds by bulls belonged to different treatment groups are given in Table 2 . Feeding Napier silage replacing rice straw at different levels to bulls had no significant ( $\mathrm{P}>0.05)$ effect on daily total DM intake (4.36, 4.50 and $4.54 \mathrm{~kg} / \mathrm{d}$, respectively). James and Butcher (1972) reported that the DM intake of a diet fed to sheep was reduced when the oxalate content in the diet was increased. The oxalate content of the diets of the present experiment varied from 0.41 to $0.68 \%$ of $\mathrm{DM}$, and appeared to be of low concentration to exert any negative effect on feed intake due to its presence in diet.

Table 2. Intake of DM and oxalate from different diets

\begin{tabular}{|l|c|c|c|c|}
\hline \multirow{2}{*}{ Parameters } & \multicolumn{3}{|c|}{ Treatments $^{\#}$} & \multirow{2}{*}{ SE } \\
\cline { 2 - 4 } & $\mathbf{T}_{\mathbf{0}}$ & $\mathbf{T}_{\mathbf{1}}$ & $\mathbf{T}_{\mathbf{2}}$ & \\
\hline DMI (Kg/d) & 4.36 & 4.50 & 4.54 & 0.10 \\
DMI (\% LW) & 1.79 & 1.82 & 1.84 & 0.04 \\
Oxalate intake (g/d) & $17.91^{\mathrm{c}}$ & $24.65^{\mathrm{b}}$ & $30.97^{\mathrm{a}}$ & 1.46 \\
Oxalate in feces(g/d) & $3.02^{\mathrm{c}}$ & $8.66^{\mathrm{b}}$ & $11.02^{\mathrm{a}}$ & 0.86 \\
\hline
\end{tabular}

${ }^{\#} \mathrm{~T}_{0}=$ Rice straw, $\mathrm{T}_{1}=$ Rice straw + silage, $\mathrm{T}_{2}=$ Silage

${ }_{\text {a,b,c }}$ Means with different superscripts are significantly different at $\mathrm{P}<0.01$

With the increase of Napier silage intake there was a significant $(\mathrm{P}<0.01)$ increase of oxalate intake (17.91, 24.56 and $30.97 \mathrm{~g} / \mathrm{d}$ for $\mathrm{T}_{0}, \mathrm{~T}_{1}$ and $\mathrm{T}_{2}$ groups of animals, respectively) with the subsequent increase $(\mathrm{P}<0.01)$ of their excretion $\left(3.03,8.66\right.$ and $11.02 \mathrm{~g} / \mathrm{d}$ for $\mathrm{T}_{0}, \mathrm{~T}_{1}$ and $\mathrm{T}_{2}$ groups of animals, respectively) through feces. Hsieh-Weinchang et al., 2004 also found a higher oxalate in feces by feeding increasing amount of Napier grass containing higher oxalate levels. A portion of oxalates is degraded in the rumen (Dodson, 1959) with the probable formation of carbonate and bicarbonate. The soluble parts of oxalate also can bind with available calcium in the rumen and be excreted in feces (Bull, 1929). This may be the probable cause of high fecal oxalate (Table 2), calcium (Table 3) and phosphorus (Table 4) contents in bulls fed Napier silage diets.

\section{Calcium balance}

It was found in Table 3 that the increasing amount of Napier silage replacing rice straw in $\mathrm{T}_{0}, \mathrm{~T}_{1}$ and $\mathrm{T}_{2}$ diets significantly $(\mathrm{P}<0.01)$ increased daily intake of calcium $(23.59,25.11$ and $26.64 \mathrm{~g} / \mathrm{d}$, respectively). Total excretion of calcium through feces and urine were 11.41, 18.25 and $25.28 \mathrm{~g} / \mathrm{d}$ for $\mathrm{T}_{0}, \mathrm{~T}_{1}$ and $\mathrm{T}_{2}$ diets, respectively. Excretions of calcium through feces of these animals were 10.54, 16.92 and $23.33 \mathrm{~g} / \mathrm{d}$, respectively and through urine were $0.87,1.33$ and $1.95 \mathrm{~g} / \mathrm{d}$, respectively. They were increased significantly $(\mathrm{P}<0.01)$ with the increase of Napier silage intake from 0 to $100 \%$. The excretions through different routes were increased linearly (Fig. $1, \mathrm{P}<0.01, \mathrm{r}=0.77$ ) with the increase of Napier silage intake from 0 to $100 \%$ or the daily intake of dietary calcium. The increasing amount of calcium intake and excretion with the increase of Napier silage intake resulted in significant $(\mathrm{P}<0.01)$ reduced calcium retention in bulls fed Napier diets. The trend of linear reduction of calcium 
balance is shown in Fig. 2 and 6. James and Butcher, 1972 also reported that the increased oxalate intake resulted in an increased calcium excretion in feces of crossbred sheep fed different levels of oxalate in the form of Halogeton.

Table 3. Calcium balance in bulls consuming different levels of Napier silage

\begin{tabular}{|l|c|c|c|c|}
\hline \multirow{2}{*}{ Parameters } & \multicolumn{3}{c|}{ Treatments $^{\#}$} & \multirow{2}{*}{ SE } \\
\cline { 2 - 4 } & $\mathbf{T}_{\mathbf{0}}$ & $\mathbf{T}_{\mathbf{1}}$ & $\mathbf{T}_{\mathbf{2}}$ & \\
\hline Ca intake (g/d) & $23.59^{\mathrm{c}}$ & $25.11^{\mathrm{b}}$ & $26.64^{\mathrm{a}}$ & 0.41 \\
Ca in feces (g/d) & $10.54^{\mathrm{c}}$ & $16.92^{\mathrm{b}}$ & $23.33^{\mathrm{a}}$ & 1.30 \\
Ca in urine (g/d) & $0.87^{\mathrm{c}}$ & $1.33^{\mathrm{b}}$ & $1.95^{\mathrm{a}}$ & 0.11 \\
Total Ca excretion (g/d) & $11.41^{\mathrm{c}}$ & $18.25^{\mathrm{b}}$ & $25.28^{\mathrm{a}}$ & 1.41 \\
Ca balance (g/d) & $12.19^{\mathrm{a}}$ & $6.87^{\mathrm{b}}$ & $1.36^{\mathrm{c}}$ & 1.12 \\
\hline
\end{tabular}

${ }^{\#} \mathrm{~T}_{0}=$ Rice straw, $\mathrm{T}_{1}=$ Rice straw + silage, $\mathrm{T}_{2}=$ Silage

${ }^{a, b, c}$ Means with different superscripts are significantly different at $\mathrm{P}<0.01$

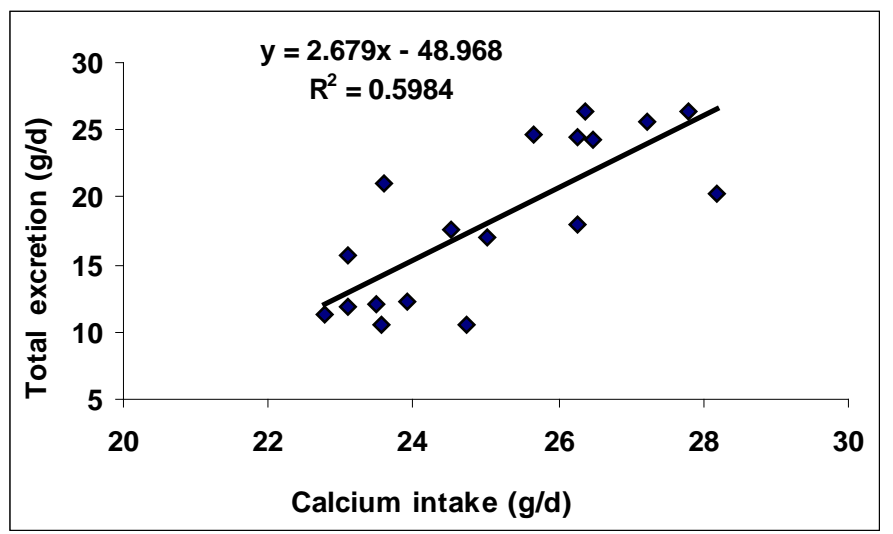

Fig. 1. Relationship between intake and excretion of calcium in bulls

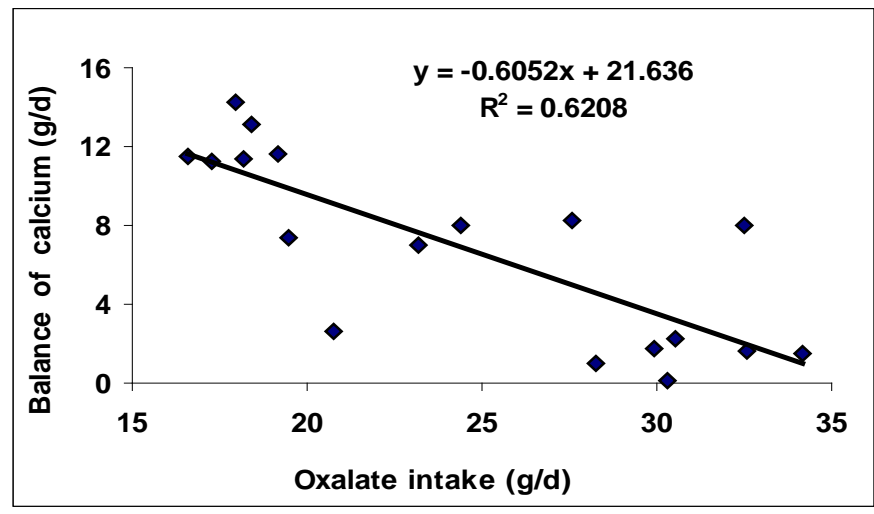

Fig. 2. Relationship between oxalate intake and balance of calcium in bulls 
Bang. J. Anim. Sci. 2010, 39(1\&2)

It is apparent from Fig. 2 and 6 that with the increase of oxalate intake there was a linear reduction of calcium balance $(\mathrm{P}<0.01, \mathrm{r}=0.79)$ in bull. It shows a reverse relationship between oxalate intake and calcium balance from a level 0.41 to $0.61 \%$ of oxalate in dry matter of the diets. The average initial live weights of the bulls used in three groups were 249, 249 and $248 \mathrm{~kg}$, and their average daily live weight gains during the experimental period of 21 days were 500, 643 and $810 \mathrm{~g} / \mathrm{d}$, respectively. At this level of gain, the daily calcium requirement might be from 13 to $16 \mathrm{~g} / \mathrm{d}$ as suggested by McDonald et al., 1981 . Except the straw diet, the Napier diets failed to supply the required amount of calcium to support for both maintenance and live weight gain of the bulls. It appeared that long time feeding of Napier might affect its availability that in turns also growth of the bulls. However, James and Butcher, 1972; Allison et al., 1981 stated that the rumen microflora can increase their oxalate degradation capacity by proliferating their population with gradually increasing oxalate diets. So, a long time ad libitum feeding of Napier silage may mitigate such mineral imbalances to some extent.

\section{Phosphorus balance}

Data on phosphorus intake and balance in bulls is shown in Table 4. The average daily phosphorus intake (20.90, 23.25 and 25.47g, respectively), similar to that of calcium of the bulls of different treatment groups increased significantly $(\mathrm{P}<0.01)$ with the inclusion of Napier silage replacing rice straw (Table 4). The total excretion of phosphorus through feces and urine for the diets $T_{0}, T_{1}$ and $T_{2}$ were $13.37,16.85$ and $20.09 \mathrm{~g} / \mathrm{d}$, respectively or individually through feces were 12.97, 15.11 and $18.09 \mathrm{~g} / \mathrm{d}$, respectively and through urine were $0.80,1.74$ and $2.00 \mathrm{~g} / \mathrm{d}$, respectively which were increased significantly $(\mathrm{P}<0.01)$ with the increase of oxalate intake in the form of Napier silage. The daily excretions of phosphorus through different routes were increased linearly (Fig. $3, \mathrm{P}<0.01, \mathrm{r}=0.94$ ) with the increasing intake of Napier silage from 0 to $100 \%$. Similar to calcium, the phosphorus balance was positive but decreased linearly (Fig. $4, \mathrm{P}<0.05, \mathrm{r}=0.50)$ from straw diet $\left(\mathrm{T}_{0}\right)$ to different levels of Napier silage diets $\left(T_{1}\right.$ and $\left.T_{2}\right)$ and the treatment differences were significant $(\mathrm{P}<0.05)$.

Table 4. Phosphorus balance in bulls consuming different levels of Napier silage

\begin{tabular}{|l|c|c|c|c|}
\hline \multirow{2}{*}{ Parameters } & \multicolumn{3}{|c|}{ Treatments $^{\#}$} & \multirow{2}{*}{ SE } \\
\cline { 2 - 4 } & $\mathbf{T}_{\mathbf{0}}$ & $\mathbf{T}_{\mathbf{1}}$ & $\mathbf{T}_{\mathbf{2}}$ & \\
\hline P intake (g/d) & $20.90^{\mathrm{c}}$ & $23.25^{\mathrm{b}}$ & $25.47^{\mathrm{a}}$ & 0.50 \\
P in feces (g/d) & $12.93^{\mathrm{c}}$ & $15.11^{\mathrm{b}}$ & $18.09^{\mathrm{a}}$ & 0.57 \\
P in urine (g/d) & $0.80^{\mathrm{b}}$ & $1.74^{\mathrm{b}}$ & $2.00^{\mathrm{a}}$ & 0.15 \\
Total P excretion (g/d) & $13.73^{\mathrm{c}}$ & $16.85^{\mathrm{b}}$ & $20.09^{\mathrm{a}}$ & 0.69 \\
P balance (g/d) & $7.17^{\mathrm{a}}$ & $6.40^{\mathrm{ab}}$ & $5.39^{\mathrm{b}}$ & 0.28 \\
\hline
\end{tabular}

${ }^{\#} \mathrm{~T}_{0}=$ Rice straw, $\mathrm{T}_{1}=$ Rice straw + silage, $\mathrm{T}_{2}=$ Silage

a,b,c Means with different superscripts within rows are significantly different either at $\mathrm{P}<0.01$ or $\mathrm{P}<0.05$ 


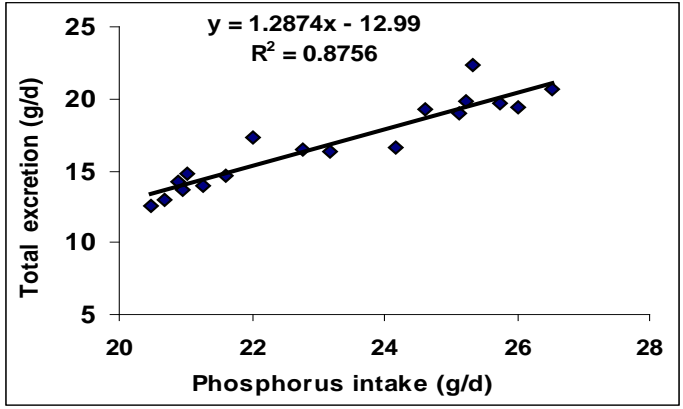

Fig. 3. Relationship between intake and excretion of phosphorus in bulls

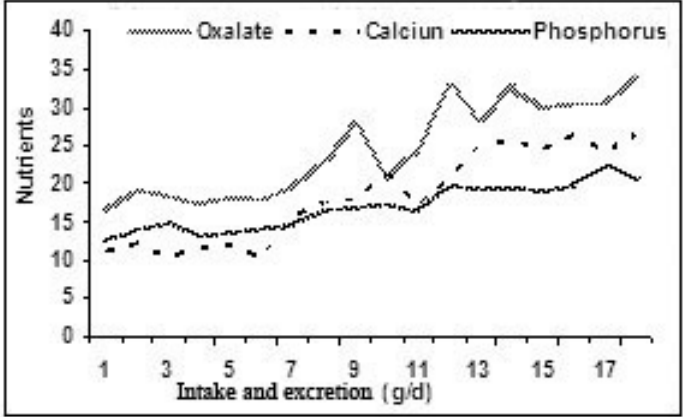

Fig. 5. Trend of oxalate intake and total excretion of calcium and phosphorus (g/d) in bull

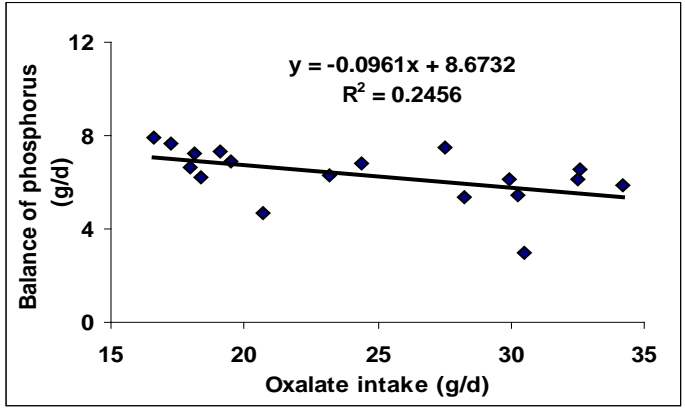

Fig. 4. Relationship between oxalate intake and balance of phosphorus in bulls

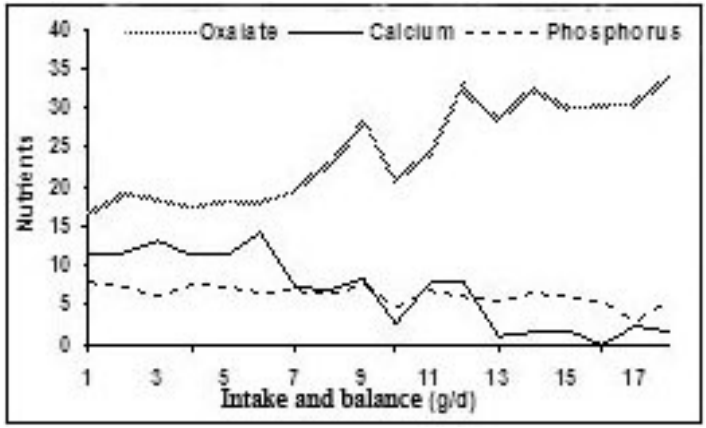

Fig. 6. Trend of oxalate intake and calcium and phosphorus balance $(\mathrm{g} / \mathrm{d})$ in bull

From Fig. 4 and 6 it appear that with the increase of oxalate intake there was a linear $(\mathrm{P}<0.05, \mathrm{r}=0.50)$ reduction of phosphorus balances in bulls which showed a reverse relationship between oxalate intake and phosphorus balance from a level 0.41 to $0.64 \%$ of oxalate content in feed dry matter. This means that the increase in total oxalate intake significantly $(\mathrm{P}<0.05)$ reduced phosphorus balance in bull due to increasing trend of excretion through different routs.

According to McDonald et al., 1981 the daily requirement of phosphorus of the bulls used in the trial varied from 8.7 to $12.0 \mathrm{~g} / \mathrm{d}$ at 500 to $810 \mathrm{~g} / \mathrm{d}$ gain during the feeding period. Similar to calcium, the phosphorus balances of the Napier diet failed to support the body requirement of bulls, and a prolonged feeding may affect the live weight gain of bulls. Dowe et al., 1957 and Alfaro et al., 1988 showed that dietary calcium to phosphorus ratio may vary from 1:1 to $7: 1$ in ruminant's diet. In this trial the ratio of calcium and phosphorus in 0,50 and $100 \%$ Napier silage diets were found 1.13, 1.08 and 1.05, respectively (Table 3 and 4). The average ratios of calcium and phosphorus balance in the three diets were 1.70, 1.07 and 0.25 (Table 3 and 4) and the decrease in calcium balance was higher than that of phosphorus. The higher reduction of calcium balance (Fig. 6) with higher excretion (Fig. 5) than that of phosphorus might be due to higher affinity of oxalate to calcium. A portion of ingested oxalate combine 
Bang. J. Anim. Sci. 2010, 39(1\&2)

with available calcium in rumen might have formed insoluble calcium oxalates and excreted in feces at a higher level than that of phosphorus (Bull, 1929).

\section{Effect of oxalate on feces DM and urine excretion}

The effects of oxalate on feces and urine excretion are given in Table 5. It is evident from the table that with the increasing intake of oxalate through Napier silage significantly $(\mathrm{P}<0.05)$ increased the average dry matter content in fresh feces (20.72, 21.51 and $23.81 \%$ for $\mathrm{T}_{0}, \mathrm{~T}_{1}$ and $\mathrm{T}_{2}$ diets, respectively). The mean urine excretion (3.02, 3.82 and $4.22 \mathrm{~L} / \mathrm{d}$ ) was also increased significantly $(\mathrm{P}<0.01)$ with the increase of Napier silage in diets.

Table 5. Effects of oxalate intake on feces and urine excretion

\begin{tabular}{|c|c|c|c|c|}
\hline \multirow[t]{2}{*}{ Parameters } & \multicolumn{3}{|c|}{ Treatments $^{\#}$} & \multirow[t]{2}{*}{ SE } \\
\hline & $\mathbf{T}_{\mathbf{0}}$ & $\mathbf{T}_{1}$ & $\mathbf{T}_{2}$ & \\
\hline DM in feces (\%) & $20.72^{b}$ & $21.51^{\mathrm{a}}$ & $23.8^{\mathrm{a}}$ & 0.41 \\
\hline DM in feces $(\mathrm{Kg} / \mathrm{d})$ & 2.28 & 2.34 & 2.41 & 0.07 \\
\hline Urine excretion (L/d) & $3.02^{\mathrm{C}}$ & $3.82^{\mathrm{b}}$ & $4.22^{\mathrm{a}}$ & 0.14 \\
\hline
\end{tabular}

${ }^{\#} \mathrm{~T}_{0}=$ Rice straw, $\mathrm{T}_{1}=$ Rice straw + silage, $\mathrm{T}_{2}=$ Silage

a,b,c Means with different superscripts within rows are significantly different at $\mathrm{P}<0.01$

Hsieh-Weinchang et al., 2004 stated that feeding increasing amount of oxalate through Napier grass increased DM content with the reduction of water content in feces. James and Butcher (1972) stated that feeding oxalate at an increasing level might have an effect on increased urine production. In this experiment dietary source of water from Napier silage might have increased water intake and resulted an increase of daily urine excretion in bulls.

\section{Conclusions}

It was concluded that the oxalate content of Napier silage may significantly reduce the balance of calcium and phosphorus in bulls that may cause retarded growth and poor body condition of bulls. Further research is needed in the form of long term feeding trial to find out the methods of feeding Napier silage to mitigate the adverse effects of oxalate on calcium and phosphorus metabolism in bull.

\section{Literature Cited}

AOAC, 1990. Official Methods of Analysis, $15^{\text {th }}$ Ed. Association of Official Analytical Chemists, Arlington, Virginia, USA.

Abaza, R. H., Bloke, J. T. and Fisher, E. J. 1968. J. Assoc. Off. Anal. Chem., 51: 963.

Alfaro, E., Neathery, M. W., Miller, W. J., Crowe, C. T., Gentry, R. P., Fielding, A. S., Pugh, D. G. and Blackmon, D. M. 1988. Influence of a wide range of calcium intakes on tissue distribution of macroelements and microelements in dairy calvrs. J. Dairy Sci., 71: 1295-1300. 
Allison, M. J., Cook, H. M. Dawson K. A. 1981. Selection of oxalate degrading rumen bacteriala in continuous cultures. J. Anim. Sci., 53: 1233-1238.

Bull, L. B. 1929. Poisoning of sheep by soursobs (Oxalis cernus): Chronic oxalic acid poisoning. Australian vet., J. 5: 60.

Dodson, M. E. 1959. Oxalate ingestion studies in the sheep. Australian vet. J., 35: 225.

Dowe, T. W., Matsushima, T. W. and Arthaud, V. H. 1957. The effects of adequate and excessive calcium when fed with adequate phosphorus in growing rations of beef cattle. J. Anim. Sci., 16: 811-820.

Fiske, C. H. and Subborow, T. 1925. Determination of phosphorus. J. Biol. Chem., 66: 375.

Hodgkinson, A. 1997. Oxalic acid in biology and medicine Academic, New York.

Hsieh-WeinChang, Wang-DeChi; Yan-ShenShyuan, Chenh-Yukuel. 2004. Comparison of different oxalate contents of Napier grass fed to yellow cattle and goats. Journal-of-Taiwan-LivestockResearch, 37(4): 313-322.

Huque, K. S., Amanullah, S. M., Islam, M. M. 2006. Impacts of fodder crop introduction into farming systems of selected areas on smallholder dairy development in Bangladesh. Annual Report (2005 \& 2006). Bangladesh Livestock Research Institute Savar, Dhaka, 1341: 107-109.

James L. F and Butcher J. E. 1972. Halogeton poisoning of sheep: Effect of high level oxalate intake. J. Anim. Sci., 35: 1233-1238.

McDonald, P., Edward, R. A. and Greenhalgh, J. F. D. 1981. Feeding standards for growing cattle; In Animal Nutrition, English Language Book Society/Longman Group Ltd, Longman House, Burnt Mill, Harlow, Essex CM20 2JE, England, 448-449.

Rahman, M. M., Niimi, M., Ishii, Y. and Kawamura, O. 2006. Effects of season, variety and botanical fractions on oxalate content of napiergrass (Pennisetum purpureum Schumach). Japanese Society of Grassl. Sci., 52:161-166.

Steel, R. G. D. and Torrie, J. A. 1980. In: Principles and procedures of statistics. McGraw Hill, New York, 120.

Varma, A. 1985. Handbook of Atomic Absorption Analysis. Vol. 1. CRC Press, Boca Raton, India. 